茶葉由来高分子ポリフェノール摂取が運動習慣のある中高齢女性の

生活体力年齢に及ぼす影響：ランダム化比較試験

武田 紘平 ${ }^{1,2}$, 田中 喜代次 ${ }^{1}$, 麻見 直美 ${ }^{1}$, 沼田 治 $^{3}$, 笹井 浩行 ${ }^{4}$, 武政 徹 $1^{*}$

\title{
Effects of high-molecular-weight polyphenol supplementation on physical fitness age in physically active middle-aged and older women: Randomized controlled trial
}

\author{
Kohei Takeda ${ }^{1,2}$, Kiyoji Tanaka ${ }^{1}$, Naomi Omi ${ }^{1}$, Osamu Numata ${ }^{3}$, Hiroyuki Sasai ${ }^{4}$ and Tohru Takemasa ${ }^{{ }^{*}}$ \\ 1筑波大学体育系， ̄305-8574 茨城県つくば市天王台 1-1-1 (Faculty of Health and Sport Sciences, University of Tsukuba, \\ 1-1-1 Tennodai, Tsukuba, Ibaraki 305-8574, Japan) \\ 2明治大学政治経済学部， ₹ 168-8555 東京都杉並区永福1-9-1 (School of Political Science and Economics, Meiji University, \\ 1-9-1 Eifuku, Suginami-ku, Tokyo 168-8555, Japan) \\ 筑波大学生命環境系， テ305-8572 茨城県つくば市天王台1-1-1 (Faculty of Life and Environmental Sciences, University \\ of Tsukuba, 1-1-1 Tennodai, Tsukuba, Ibaraki 305-8572, Japan) \\ ${ }^{4}$ 東京都健康長寿医療センター研究所，１73-0015 東京都板橋区栄町35-2 (Tokyo Metropolitan Institute of Gerontology, \\ 35-2 Sakae-cho, Itabashi-ku, Tokyo 173-0015, Japan)
}

Received: October 12, 2020 / Accepted: February 6, 2021

\begin{abstract}
Mitochondria activation factor (MAF) which is high-molecular weight polyphenol contained in black tea and oolong tea can increase the mitochondrial membrane potential. MAF supplementation to mice facilitates endurance running performance after 9-week endurance training and muscle hypertrophy induced by synergist ablation. In this study, we examined the effect of oral MAF supplementation on overall physical fitness (expressed as physical fitness age) in physically active middle-aged and older women. This study is a randomized doubleblind placebo-controlled trial implemented between January and May 2019 at three fitness facilities in Ibaraki, Japan. Seventy middle-aged women aged 55 to 69 years were randomly assigned into placebo $(n=35)$ and MAF groups $(n=35)$. The placebo participants took cornstarch-containing capsules, and the MAF participants took MAF-containing capsules twice a day for 80 days consecutively. During the intake period, all participants were instructed to follow 30-min circuit training program at least twice a week. Physical fitness age was computed with eight physical fitness items assessing upper-extremity muscle strength, locomotion, and postural change. The physical fitness age decreased by 1.48 years $(95 \%$ confidence interval $[\mathrm{CI}]$ : $-2.66,-0.30)$ in the placebo group and 3.01 years $(95 \%$ CI: $-4.16,-1.86)$ in the MAF group. The reduction was greater in the MAF group, but did not reach statistical significance $(p=0.06)$. The combination of 80-day of MAF intake and circuit exercise showed beneficial results. However, our results did not indicate clear effects on physical fitness age because of low statistical power. Further studies are necessary to reveal the effects of MAF supplementation.
\end{abstract}

Jpn J Phys Fitness Sports Med, 70(3): 199-205 (2021)

Keywords : mitochondria activation factor (MAF), exercise, physical fitness age, bone mineral density, fat mass

緒言

お茶は古くから親しまれている飲料であり，お茶を飲 むことの健康効果が明らかになりつつある。メ夕解析に

*Correspondence: takemasa.tohru.gm@u.tsukuba.ac.jp

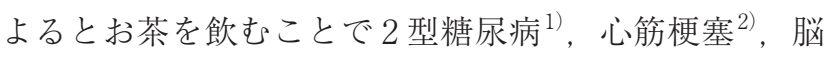
卒中 ${ }^{3)}$ リスクを下げることが報告されている。これらの 結果は，扔茶に含まれるカテキンやエピガロカテキンガ レート（EGCG）などのポリフェノールの持つ生理活性 によるものだと考えられている ${ }^{4)}$. 我々はこれまで，紅 茶や烏龍茶などの発酵茶に含まれるポリフェノールの生 
理活性に着目し，基礎研究を行ってきた。このポリフェ ノールは分子量が9,000から 18,000であり, カテキン（分 子量：290) やEGCG（分子量：458）と比較し, カテキ ン骨格を持つポリフェノールが酸化重合により多量体化 したという特徴がある ${ }^{5)}$.この高分子ポリフェノールを 原生生物の繊毛虫テトラヒメナに添加したところ, ミト コンドリア膜電位が上昇した ${ }^{5)}$ 。この結果より, 発䤉茶 由来の高分子ポリフェノールを mitochondria activation factor (MAF) と命名した。このMAFをマウスに摂取 させ，持久性トレーニング (分速 $15 \mathrm{~m}$ で 30 分間のトレッ ドミル走）を週に 5 日，9週間にわたって継続した研究 では，持久性トレーニングのみを行った群と比較し，持 久力が向上していた ${ }^{6)}$.また，マウスの筋肥大を惹起す る協働筋切除手術による14日間の代償性過負荷の検討 では，代償性過負荷のみの群と比較し，MAFを約 $25 \%$ 含む $\mathrm{E} 80$ 摂取と代償性過負荷を併用した群の方が，筋 肥大の程度が大きかった ${ }^{7)}$ 。このような先行研究より, MAF 摂取と運動刺激を組み合わせると骨格筋適応が高 まる可能性が考えられる。しかしながら，これまでに ヒトに扒いて MAF摂取と運動を組み合わせることによ る体力や身体組成に及ぼす影響を検証した報告はない。 将来的にMAFをサプリメントとして実用化するために は, ヒトを対象とした研究は必須であることから, 本研 究では継続したMAF摂取とサーキット運動の組み合わ せが身体組成および総合的な体力の指標である生活体力 年齢（健康寿命と密接な関係にあるとされる）に及ぼ す影響を明らかとすることを目的として，中高齢女性を 対象に検討した。中高齢女性を対象とした理由は, 超高 齢化社会を迎えた日本に打いて, MAF摂取が中高齢者 の生活体力年齢に及ぼす影響を確認したかったためであ る。さらに，集団での運動教室に積極的に参加する女性 を対象とした。

\section{方 法}

研究デザイン 本研究は二重盲検化並行群間ランダム化 比較試験である。本研究のデー夕は茨城県つくば市抢よ び土浦市に㧈いて 2019 年 1 月から 5 月の間に収集され た、デー夕の解析は 2019 年 5 月に行った。必要サンプル サイズの事前計算は行っておらず, 予算の関係上 70 名に 設定した。本研究は事前に筑波大学体育系研究倫理委員 会の承認（体30-60号, 2018年11月20日）を得た上で実 施した。本研究プロトコルはUMIN 臨床試験登録システ ムに2019年 5 月 6 日に登録した (UMIN000036638)。本 論文は, ランダム化比較試験の標準的な報告ガイドライ ンであるCONSORT 声明 ${ }^{8)}$ に従って記述した。

研究に先立って, 事前説明会を開催し, 研究参加者に は研究の目的抢よび研究参加に伴う危険性について口頭 で十分に説明し, 研究参加の同意を書面で得た。同日に
身長と体重測定, 生活体力年齢算出のために 8 項目の体 力測定を抢こなった。事前説明会から約 2 週間後に二重 エネルギーX $\mathrm{X}$ 線吸収法 (dual-energy X-ray absorptiometry：DXA）により身体組成を測定した。研究参加に対 する金銭報酬はなかったが，株式会社カーブスジャパン からオリジナルスポーツウェアやスポーツシューズ等 （3,000〜4,000円相当）が謝礼として贈呈された.

研究参加者 研究参加者は茨城県つくば市と土浦市にあ る株式会社カーブスジャパンが開設する健康体操教室 (以下, カーブス) の 3 つの店舗に本研究の研究参加者募 集ポスターを揭示して募集した，研究参加者の採択基準 は（1）カーブスに週 2 回以上参加するサーキット運動 習慣のある人,（2）55歳から69歳の中高齢女性とした。 カーブスでの運動歴は特に採択基準としていない。除外 基準は重篤な疾患を持っている人とした，採択基準に合 致し，除外基準に合致しない参加希望者が70名を超えた 場合は, 体重, BMI, 年齢を考慮し, 研究代表者（武政） の判断により, 70名を超えた希望者を研究から除いた.

ランダム化と盲検化 群間で介入前の体重を揃えつつ, 各群を同数とするため研究参加者 70 名を体重で昇順に並 ベ替えた後, MAF群, プラセボ群, プラセボ群, MAF 群の順でランダム割付した. ランダム化は割付責任者（武 田）が行った。 ランダム化コードはパスコードがかかっ たパーソナルコンピュータ内に保存し, サプリメント配 布準備のみに利用した。サプリメント摂取期間後の測定 終了後にデータをクリーニングし, 固定した後に, ラン ダム化コードを開示した。盲検化の範囲は研究参加者, 割付責任者（武田）を除く研究者ならびにスタッフであっ た。試験食品配布責任者（武政）と割付責任者（武田） は介入前後の体力測定・DXA 測定の場にスタッフとし て居合わせていたが, 生活体力年齢の換算に使われる 8 項目の体力測定には関与していない. したがって検出バ イアスのリスクは極めて小さいと考えられる.

サプリメント 研究参加者には, プラセボもしくは MAFのサプリメントカプセルを渡し, 朝食後, 昼食後 の 1 日 2 度, 80 日間摂取してもらうよう依頼した。サプ リメントカプセルはサプリメント摂取前のDXA測定時 にランダム化コードを盲検化した試験食品配布責任者 (武政) が研究参加者へ手渡した.MAF群の研究参加者 には, MAF180901を300 mg充填したカプセルを渡し, 対照群には約 $270 \mathrm{mg}$ のコーンスターチを充填したカプ セルを渡した。サプリメントカプセルは光を透過しない チャック式アルミ袋に入れた.MAF180901は，原料の カテキンを酵素であるポリフェノールオキシダーゼを用 いて人工的に酸化重合させ，作成した，MAF180901の 
組成は, 岩浅らの手法 ${ }^{9)} に よ り$ 同定した.MAF180901は MAF (約 34\%), テアフラビン類 (約 47\%), カテキン類 (約 $2.3 \%)$, カフェイン (約 $2 \%$ ) を含んでいた (Table 1). 約 16\%の残成分については，3\%前後の水分と HP20（ス チレンージビニルベンゼン共重合体）に親和性をもつテ ルペノイド, 脂質, 色素, クロロフィル系物質, アルカ ロイド, サポニン, タンパク質等が含まれると推定され る. MAF180901は日本では商品名コレスパート 10) とし て市販されているサプリメントとほほ同等の組成をして おり，8 年以上日本をはじめ, アメリカ, 中国で流通し ている。これまで本製品摂取による有害事象報告はない ことから, MAF摂取に対する安全性は担保されている と考えられる．視覚的にサプリメント内容物が判別でき ないよう，それぞれのサプリメントは茶色に着色したカ プセルに充填した。サプリメント摂取量は体重 $50 \mathrm{~kg}$ 未 満の研究参加者は朝食後 4 粒, 昼食後 5 粒, 体重 $50 \mathrm{~kg}$ 以上 $70 \mathrm{~kg}$ 未満の研究参加者は朝食後 5 粒, 昼食後 5 粒, 体重 $70 \mathrm{~kg}$ 以上の研究参加者は朝食後 5 粒, 昼食後 6 粒 摂取するよう指示をした。サプリメント摂取量は, 摂取 期間中の体重変化を考慮せず固定した。また，各サプリ メントの日ごとの摂取状況については研究参加者に日誌 に記録するよう依頼した，MAF摂取量については, マ ウスを用いた実験で得られた結果（未公表データ）を元 に，ヒト等価容量の計算式より算出した。茶葉由来のポ リフェノールは分子量が高いほど腸での吸収率が悪いこ とが示されている ${ }^{11)}$ ，我々の動物実験でもMAFを水や 餌に混合することで，少量を長時間にわたり体内に残る よう摂取するようにした ${ }^{6,7,12)}$ 。このような経緯はあるが, 本研究では現実的な摂取法として 1 日 2 回の分割摂取を 行なった. 研究参加者には本研究で配布したサプリメン

\begin{tabular}{lr} 
Table 1. Composition of MAF180901 & (\%) \\
\hline MAF & 34.00 \\
Theaflavin 1 & 7.13 \\
Theaflavin 2A & 12.30 \\
Theaflavin 2B & 7.86 \\
Theaflavin 3 & 17.77 \\
Gallic acid & 0.04 \\
Gallocatechin & 0.00 \\
Epigallocatechin & 0.05 \\
Catechin & 0.05 \\
Epigallocatechin gallate & 0.23 \\
Epicatechin & 0.17 \\
Gallocatechin gallate & 0.03 \\
Epicatechin gallate & 1.51 \\
Catechin gallate & 0.29 \\
Caffeine & 1.99 \\
Water, Terpenoid, Fat etc. & Approx. \\
\hline Total & 100.00
\end{tabular}

トの他に，プロテインの摂取状況についても記録するよ う求めた。サプリメント摂取期間中は，通常の食事を維 持するように指示した。

サーキット運動プログラム 研究参加者にはサプリメン 卜摂取期間に株式会社カーブスジャパンが開設する健康 運動教室に週 2 回以上通い, サーキット運動プログラム に参加するよう指示をした。 カーブスで行うワークアウ トは，マシンを使った筋力トレーニング（30秒）とその 場ステッピングによるクーリングダウン（30秒）を交 互に行うサーキット運動である。筋力トレーニングは主 に上半身を鍛える 6 種目（チェストバック，ショルダー プレス, バイセップ・トライセップ, ペックデック, ラテ ラルリフト,オブリーク）と主に下半身を鍛える 6 種目 （レッグエクステンション・レッグカール, スクワット， ヒップアブダクター, レッグプレス, グルート, アブバッ ク）を交互に行えるように計 12 種類のマシンが配置され ており，このサーキットトレーニングを 2 周回すため計 24分，最後にストレッチを行い，30分で 1 回のプログラ ムは完了する。研究参加者には，日ごとのサーキット運 動プログラム実践状況を記録してもらった。サーキット 運動プログラムの指導は株式会社カーブスジャパンに勤 務する従業員が行った，運動プログラム中は 8 分に一度, 従業員の指示のもと心拍数測定を行った。最大心拍数の 60〜80\%より高くなる場合は，ペースを落として運動 強度の調整を行った。

測定項目 本研究では, 田中ら ${ }^{13)}$ が提唱した生活体力年 齢を主要解析項目とした. 生活体力年齢は, ヒトの筋力, 筋持久力，平衡性，敏捷性，柔軟性，巧緻性などを総合 的に評価し, 高齢者の体力を評価する年齢尺度である。 本研究では中高年女性を対象としており, 日常生活にお ける体力を簡便に測定・評価できることを企図して，生 活体力年齢を採用した。副次解析項目は, 生活体力年齢 算出のために測定した握力, 閉眼片足立ち, 長座体前屈, 起立時間, 連続上腕屈伸, 8 の字歩行, ファンクショナ ルリーチ，連続立ちあがり動作と，DXAにより定量し た骨塩量, 骨密度, 脂肪量, 除脂肪量, 体脂肪率とした。

生活体力年齢 生活体力年齢を算出するため, 握力, 閉 眼片足立ち, 長座体前屈, 起立時間, 連続上腕屈伸, 8 の字歩行，ファンクショナルリーチ，連続立ちあがり動 作の 8 項目を測定した。それぞれの測定方法は薮下らの 研究 ${ }^{14)}$ を参考に, Supplemental methodsに記述する.

身長, 体重, 身体組成 身長は身長計 (日本医療器研究所, 日医-77710）を用いて, 体重は体重計（株式会社夕ニタ, MC-190）を用いて測定した。脂肪量, 除脂肪量, 骨密度, 
骨塩量ならびに骨面積はDXA 法（ホロジック株式会社, Holyzon）を用いて測定した。 DXA測定における各CV

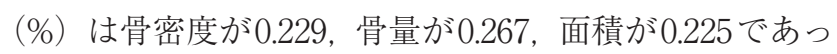
た. 高・低エネルギーの減弱係数比 $\mathrm{k} は 0.097$, 骨密度計 算時の補正係数 $\mathrm{d} 0$ は 0.22 であった. 脂肪量ならびに除脂 肪量は全身, 頭部, 左腕, 右腕, 胴体, 左脚, 右脚につ いて測定した。骨密度, 骨塩量, 骨面積は全身, 左腕, 右腕, 左肋骨, 右肋骨, 胸椎, 腰椎, 骨盤, 左脚, 右脚 について測定した。研究参加者に対して, DXA測定の 3 時間前からは水以外のものは摂取しないよう促した.

統計解析 デー夕は統計分析フリーソフトR (3.2.4 for Windows 64 bit）を用いた。サプリメント摂取期間前の 研究参加者の特性は平均值ならびに標準偏差で示した。 CONSORT 声明の推奨に従い主要な解析は intentionto-treat（ITT）法に基づき, 久落したデータはサプリメ ント摂取期間前のデータを用いて補完した。主要評価項 目ならびに副次評価項目は平均值と $95 \%$ 信頼区間で示し た. Welch検定により群間差を検証した。統計学的有意 水準は $5 \%$ に設定した。

\section{結 果}

研究参加者のフローチャートを Fig. 1に示す. ポスター 掲示を見て, 85名が研究参加の意志を示したが, 事前説 明会前に 5 名が研究参加を辞退した。事前説明会兼体力 測定会には 80 名が参加したが, 説明会後に 1 名が参加を 辞退した. 研究代表者（武政）の判断により残った 79 名
から体重の最も重い 3 名と最も軽い 3 名を除外した。さ らに残った 73 名から BMI值が最も高い 2 名と最も低い 1 名を除外し, 研究参加者 70 名を決定した. 70 名の研究 参加者をプラセボ群 $(\mathrm{n}=35)$ と MAF 群 $(\mathrm{n}=35)$ をラ ンダムに分け，介入を開始した。サプリメント摂取期間 後の体力測定を辞退した研究参加者が 3 名いたが，その 理由はサプリメント摂取で腹部が張る, 帯状疮疹, 内視 鏡検査に備えるためであった。サプリメント摂取で腹部 が張った研究参加者と帯状疮疹の研究参加者はプラセボ 群に属する研究参加者であった。

80 日間のサプリメント摂取率はプラセボ群, MAF群 それぞれ平均 $96.9 \%, 93.2 \%$ で,プラセボ群で有意に摂取 率が高かった（p=0.01）。また，サーキット運動プログ ラムへの参加状況はプラセボ群, MAF群それぞれ平均 3.11回/週，2.97回/週であった $(\mathrm{p}=0.55) .80$ 日間のサ プリメント摂取による重篤な有害事象は報告されなかっ た. 各群のプロテインの摂取状況はプラセボ群で16名, $\mathrm{MAF}$ 群は 17 名であった $(\mathrm{p}=0.89)$.

介入前の各群の特性をTable 2 に示す。デー夕は平均 值 (標準偏差) で示してある. 生活体力年齢, 体力測定, 体組成の各項目について両群間に有意差はなかった，

主要評価項目ならびに副次評価項目の結果を Table 3 に示す。それぞれのデー夕は平均值（95\%信頼区間）で 示してある。主要評価項目である生活体力年齢では，プ ラセボ群で1.48歳, MAF群では3.01歳低下していたが, 両群間に有意な差は認められなかった。副次的評価項目 の 1 つである片足閉眼立ちはプラセボ群に比べて MAF

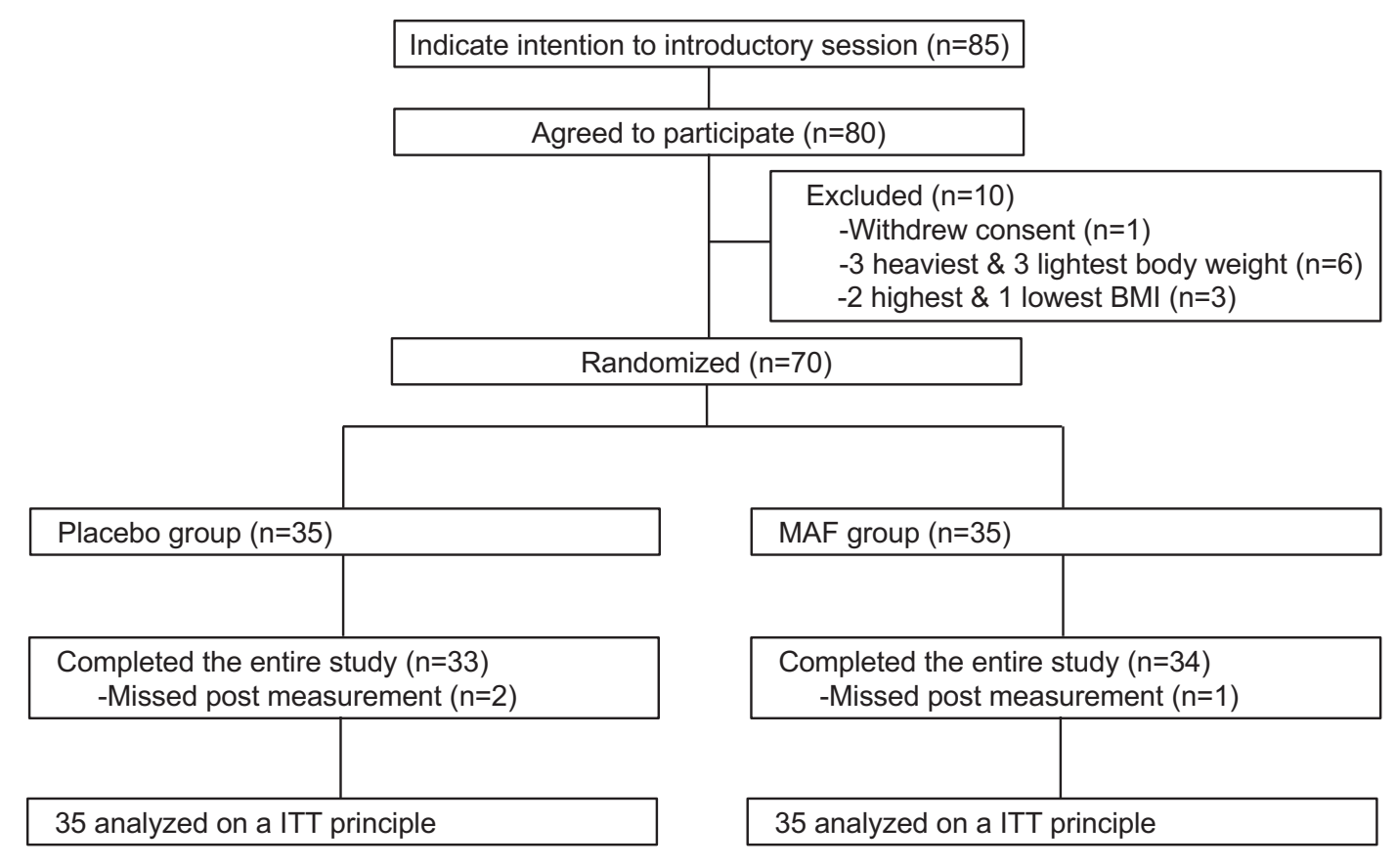

Fig. 1 Flowchart of study participants

Abbreviations: BMI, body mass index; MAF, mitochondrial activation factor; ITT, intention to treat. 
Table 2. Baseline participants characteristics

\begin{tabular}{lll}
\hline & Placebo $(\mathrm{n}=35)$ & MAF $(\mathrm{n}=35)$ \\
\hline Demographics & & \\
Age, years & $61.23(4.18)$ & $61.57(3.69)$ \\
Height, cm & $154.8(5.1)$ & $155.7(5.2)$ \\
Weight, kg & $56.7(7.0)$ & $56.8(7.6)$ \\
BMI, kg/m² & $23.69(2.85)$ & $23.46(3.17)$ \\
Physical fitness & & \\
Grip strength, kg & $22.8(3.9)$ & $23.6(3.3)$ \\
Balancing on one leg with eye closed standing, sec & $6.83(10.68)$ & $5.53(4.44)$ \\
Sit and reach, cm & $39.3(7.9)$ & $39.8(6.8)$ \\
Stand-up from lying position, sec & $2.89(0.88)$ & $2.84(1.14)$ \\
Arm curl, n/30 sec & $25.6(3.2)$ & $25.5(4.8)$ \\
Walking around two cones in figure 8, sec & $22.6(2.7)$ & $22.7(2.8)$ \\
Functional reach, cm & $34.0(5.9)$ & $34.8(5.7)$ \\
Chair stand, n/30 sec & $24.9(5.5)$ & $25.2(5.8)$ \\
Physical fitness age, years & $54.1(6.7)$ & $53.8(8.4)$ \\
Body composition & & \\
Bone mineral content, g & $1639(219)$ & $1627(173)$ \\
Bone mineral density, g/cm ${ }^{2}$ & $0.94(0.09)$ & $0.92(0.07)$ \\
Fat mass, kg & $19.67(4.59)$ & $19.47(5.39)$ \\
Fat-free mass, kg & $38.04(3.47)$ & $38.24(3.51)$ \\
Fat mass, \% & $33.7(4.5)$ & $33.2(5.8)$ \\
\hline Data shown as mean (stan)
\end{tabular}

Data shown as mean (standard deviation).

Table 3. Changes in primary and secondary outcomes during the 80 -day intervention period $(\mathrm{n}=70)$

\begin{tabular}{llll}
\hline & Placebo $(\mathrm{n}=35)$ & $\mathrm{MAF}(\mathrm{n}=35)$ & P value for t-test \\
\hline $\begin{array}{l}\text { Primary outcome } \\
\text { Physical fitness age, years }\end{array}$ & $-1.48(-2.66,-0.30)$ & $-3.01(-4.16,-1.86)$ & 0.06 \\
Secondary outcomes & $1.89(0.89,2.88)$ & $1.11(0.45,1.76)$ & 0.19 \\
Grip strength, kg & $-1.57(-4.36,1.23)$ & $2.05(-0.04,4.14)$ & 0.04 \\
Balancing on one leg with eye closed standing, sec & $0.24(-0.98,1.45)$ & 0.12 \\
Sit and reach, cm & $-0.96(-1.87,-0.04)$ & $-0.23(-0.47,0.01)$ & 0.95 \\
Stand-up from lying position, sec & $-0.24(-0.46,-0.02)$ & $4.49(3.35,5.63)$ & 0.16 \\
Arm curl, n/30 sec & $3.40(2.33,4.47)$ & $-2.24(-2.77,-1.71)$ & 0.57 \\
Walking around two cones in figure 8, sec & $-2.03(-2.59,-1.46)$ & $-3.89(-5.45,-2.33)$ & 0.98 \\
Functional reach, cm & $-3.86(-5.64,-2.08)$ & $2.17(0.67,3.67)$ & 0.08 \\
Chair stand, n/30 sec & $0.46(-0.85,1.76)$ & $-11.5(-24.9,1.9)$ & 0.44 \\
Bone mineral content, g & $-5.3(-14.5,4.0)$ & $0.0036(-0.0012,0.0084)$ & 0.74 \\
Bone mineral density, g/cm 2 & $0.0048(-0.0005,0.0101)$ & 0.50 \\
Fat mass, g & $-467.6(-712.7,-222.5)$ & $-343.1(-621.6,-64.5)$ & 0.44 \\
Fat-free mass, g & $375.0(146.6,603.5)$ & $530.4(190.7,870.1)$ & 0.92 \\
Fat mass, \% & $-0.78(-1.12,-0.44)$ & $-0.75(-1.19,-0.30)$ & 0.96 \\
\hline
\end{tabular}

Data shown as mean (95\% confidence intervals).

Missing observations at post-intervention measurement $(n=3)$ were replaced based on a baseline observation carried forward rule.

群で有意に記録が大きく向上した。その他の測定項目に ついて, プラセボ群と MAF群の間に有意な差は認めら れなかった。主要評価項目ならびに副次評価項目以外の 測定項目についてはSupplemental tableに示してある.

\section{考察}

本研究の目的は, 80 日間の発酵茶葉由来高分子ポリ フェノール MAF 摂取が運動習慣のある中高齢女性の生 活体力年齢ならびに身体組成に及ぼす影響を明らかとす ることであった８0日間のサーキット運動により，主要 評価項目である生活体力年齢の低下はプラセボ群と比較 してMAF群で大きかったが，有意差は認められなかっ
た。また，除脂肪量，脂肪量，骨密度などにMAF摂取の 効果は認められなかった。 80 日間のMAF摂取による重 篤な有害事象は報告されなかった。

生活体力年齢の改善はMAF群で大きかったが, 両群 間で有意差は認められなかった。これまで動物実験から $\mathrm{MAF}$ 摂取には持久力向上と筋肥大促進の効果が想定さ れている。持久性トレーニングに MAF 摂取を組み合わ せることで，持久性トレーニングのみの条件と比較し， 骨格筋での AMPK（AMP-activated protein kinase）活 性化レベルが高く，GLUT4（glucose transporter4）の mRNA 量が多くなっていた。一方で, MAF摂取のみで これらの適応は認められなかった ${ }^{6)}$. 筋肥大研究では, 
MAF 摂取条件では筋肥大シグナルである p70S6K（p70 ribosomal protein S6 kinase) とS6のリン酸化レベルが 高かった ${ }^{7)}$. MAF 摂取と運動を組み合わせることでこ れらメカニズムにより骨格筋適応がより高まる可能性が 考えられている。 しかし, 本研究の主要評価項目である 生活体力年齢は筋力, 筋持久力だけでなく敏捷性, 柔軟 性など総合的な体力要素から算出している.したがって, 動物実験の結果から想定される MAF 摂取の効果に評価 項目を絞ることで，その影響について明確にすることが できる可能性がある。 また, 本研究の筋力トレーニング は油圧式マシンを使用していることから, 骨格筋への負 荷は研究参加者の反復速度に比例して大きくなる，本研 究では筋力トレーニングの反復速度に関して研究参加者 へ特に指示をしていないため, 研究参加者の筋にかかっ た負荷について十分に検討することができない．この点 に関して本研究と同じサーキット運動を採用した研究で は運動時に音楽やリズムに合わせて運動を行うことで適 切な運動負荷がかかり, 正確なサーキット運動の効果を 引き出すことができると考察している ${ }^{15)}$. MAFの持つ 作用を明らかとするため, 今後は研究デザインの改善な どを行い, 研究を継続していく必要がある.

生活体力年齢算出のために測定した 8 項目のうち, 片 足閉眼立ちにのみ群間に有意差が認められ, MAF群で 改善が大きかった。この理由として，プラセボ群の 1 名 の記録がサプリメント摂取期間後に大きく低下したた め, 群全体の結果に影響したことが考えられる。これま での研究結果から片足閉眼立ちと下肢筋力, 足趾筋力, 足底二点識別覚 (足底感覚) などの能力が関連するこ とが報告されている ${ }^{16-18)}$. 研究参加者が行なった下肢の サーキット運動プログラムは下肢筋力向上が主目的であ り, 足趾筋力や足底二点識別覚に及ぼす影響については 不明である. したがって, 本研究での片足閉眼立ちの群 間差に関しては, サプリメント摂取やサーキット運動以 外の要因が影響した可能性も考えられる. 他の 7 項目に ついて, プラセボ群と MAF群の間に有意差はなかった ことから単独の体力要素には顕著な影響はなかったが, 総合的には好ましい方向にあることが観察された。

副次評価項目である体脂肪量, 除脂肪量, 骨密度につ いてはプラセボ群と MAF群との間に有意な差は認めら れなかった. 主要評価項目と副次評価項目に含まれない 右腕骨密度, 腰椎骨密度, 左脚脂肪量の 3 項目について 両群間に有意差が認められた。右腕骨密度はMAF摂取 で増加していたが, 腰椎骨密度ではMAF摂取では減少 していた。 また, 左脚脂肪量はプラセボ群で減少量が有 意に大きかった，研究参加者へは事前に通常通りの食事 を維持するよう指示をして扔り, サプリメント摂取によ り骨密度の部位特異性もしくは体組成の非対称性が生ま れるとは生理学的に考えにくいため, これらの有意差は
測定誤差であると考えられる。これまでの動物実験では MAF 摂取と運動の組み合わせが脂肪量や骨密度に及ぼ す影響に関して検討を行っていない.しかし，MAFを $25 \%$ 含むE80混合した慨を自由摂取した研究では, 通常 食を自由摂取したマウスと比較して摂食量と体重に差は なかった ${ }^{7)}$.したがって, MAF摂取と運動の組み合わせ が身体組成や骨密度に及ぼす影響は小さい可能性が考え られる。

本研究が持つ新規性として原生生物である繊毛虫やマ ウスを使ってミトコンドリアを活性化することを分子レ ベルで検証した茶葉由来高分子ポリフェノールを含む原 末を使っていることが挙げられる。基礎研究の延長に本 研究は成り立って抢り, 今後ヒ卜に対する研究成果を重 ねることで健康寿命延伸に寄与するサプリメントを開発 できる可能性がある.

本研究の限界としていくつか挙げられる，まず，研究 参加者数が不十分である. 本研究では予算の関係上研究 参加者を 70 名に制限したが, 統計学的検出力が不足し ている可能性がある. 実際に本研究結果から $\alpha$ エラー $0.05, \beta$ エラー 0.2 , 両側検定の条件で事後的に計算す ると, 効果量 (Cohen's d) は 0.43 となった。これに基 づけば, 一群当たり 86 人, 計 172 人必要となる計算とな り, 本研究の対象者数はこれよりも明らかに少ない，得 られた結果の信頼性を高めるためにも研究参加者を増や すことを今後の課題としたい。続いて, 研究対象者に対 してサプリメント摂取期間中の食事調査を行なっていな い点である。本研究では事前に普段と変わらない食事を 行うよう指示をした。 しかし, サプリメント摂取期間中 の栄養状態を把握できていないことから, 食事内容の変 化がサプリメント摂取効果に影響した可能性を否定で きない，最後にMAFカプセルに含まれる MAFの純度 が低いことである。本研究で用いた MAFカプセルには MAFが34\%しか含まれて扔らず，テアフラビンなどの 茶ポリフェノールが半分ほど含まれている。したがって, 現在の原末ではMAFに特異的な生理活性を評価できて いない，現時点で純度の高いMAFを精製する方法は確 立されておらず, 今後はMAFの合成·精製方法を検討し, それにより得られた純度の高いMAFを含むサプリメン トカプセルを生産することで, MAF 単体の生理活性を より正確に評価することが可能となる。

80 日間の MAF 摂取とサーキット運動を組み合わせる ことで生活体力年齢は好ましい方向の結果は得られたも のの, 統計学的検出力の不足により生活体力年齢の改善 に対する有効性を主張できる結果は得られなかった，今 後はMAF摂取がヒトの身体に及ぼす影響を明らかとす るため, 研究参加者の選定やサンプルサイズを含めさら なる検討が必要である. 


\section{利益相反申告}

本研究は株式会社カーブスジャパン社から受けた共同研 究費 (研究代表者：武政徹）により実施した。ただし, 株式 会社カーブスジャパン社は本研究での研究参加者の募集と トレーニングの指導にのみ関与し, 研究参加者の群わけ, データ収集, 結果解釈や結論には関与していない.

本研究で使用されているサプリメントは「特許第5439644 号 ウーロン茶又は紅茶から抽出された血糖值上昇抑制剤及 びミトコンドリア膜電位上昇剤」に含まれるものとは製造 方法が異なるものであるが, 成分分析により同等の成分が 含まれていると考えている.

\section{著者貢献}

武田紘平, 田中喜代次, 麻見直美, 沼田治, 武政徹は研究 デザインとプロトコルを概念化し, 研究機関を決定した。 武田紘平, 田中喜代次, 麻見直美, 沼田治, 武政徹は体力測 定, DXA 測定, データ収集を担当した。笹井浩行はデータ 分析と解釈を担当した。草稿は武田紘平が執筆した。すべ ての著者は，最終原稿を熟読した上で，投稿を承認した．

\section{電子付録}

Supplemental table, methods

\section{文献}

1) Huxley R, Lee CM, Barzi F, Timmermeister L, Czernichow S, Perkovic V, Grobbee DE, Batty D, and Woodward M. Coffee, decaffeinated coffee, and tea consumption in relation to incident type 2 diabetes mellitus: a systematic review with meta-analysis. Arch Intern Med 169: 2053-2063, 2009. doi: 10.1001/ archinternmed.2009.439.

2) Peters U, Poole C, and Arab L. Does tea affect cardiovascular disease? A meta-analysis. Am J Epidemiol 154: 495-503, 2001. doi: 10.1093/aje/154.6.495.

3) Arab L, Liu W, and Elashoff D. Green and black tea consumption and risk of stroke: a metaanalysis. Stroke 40: 1786-1792, 2009. doi: 10.1161/ STROKEAHA.108.538470.

4) Yang CS and Hong J. Prevention of chronic diseases by tea: possible mechanisms and human relevance. Annu Rev Nutr 33: 161-181, 2013. doi: 10.1146/annurev-nutr-071811-150717.

5) Fujihara T, Nakagawa-Izumi A, Ozawa T, and Numata O. High-molecular-weight polyphenols from oolong tea and black tea: purification, some properties, and role in increasing mitochondrial membrane potential. Biosci Biotechnol Biochem 71: 711-719, 2007. doi: 10.1271/bbb.60562.
6) Eguchi T, Kumagai C, Fujihara T, Takemasa T, Ozawa T, and Numata O. Black tea high-molecularweight polyphenol stimulates exercise traininginduced improvement of endurance capacity in mouse via the link between AMPK and GLUT4. PLoS One 8: e69480, 2013. doi: 10.1371/journal.pone.0069480.

7) Aoki Y, Ozawa T, Takemasa T, and Numata O. Black tea high-molecular-weight polyphenol-rich fraction promotes hypertrophy during functional overload in mice. Molecules 22: 548, 2017. doi: 10.3390/molecules22040548.

8) Schulz KF, Altman DG, Moher D, and CONSORT Group. CONSORT 2010 statement: updated guidelines for reporting parallel group randomized trials. Ann Intern Med 152: 726-732, 2010. doi: 10.7326/0003-4819152-11-201006010-00232.

9）岩浅 潔, 鳥井秀一：酒石酸鉄による茶タンニンの比色 定量法, 茶業研究報告, 1962: 104-108, 1962. doi: 10.5979/ cha.1962.104

10) Available from: http://www.nutrilite.jp/content/nt/ products/cholexpert.html.

11) Lipinski CA, Lombardo F, Dominy BW, and Feeney PJ. Experimental and computational approaches to estimate solubility and permeability in drug discovery and development settings. Adv Drug Deliv Rev 46: 3-26, 2001. doi: 10.1016/s0169-409x (00)00129-0.

12) Aoki Y, Ozawa T, Numata O, and Takemasa T. Highmolecular-weight polyphenol-rich fraction of black tea does not prevent atrophy by unloading, but promotes soleus muscle mass recovery from atrophy in mice. Nutrients 11: 2131, 2019. doi: 10.3390/nu11092131.

13）田中喜代次, 木塚朝博, 大藏倫博：健康づくりのための 体力測定評価法, 金芳堂, 京都, 2007.

14）藪下典子, 吉川和利, 坂井智明, 中村容一, 田中喜代次 : 高齢男性における体力年齢推定式の提案, 民族衞生, 70: 196-206, 2004. doi: 10.3861/jshhe.70.196.

15）大㴊修一, 河合 恒, 光武誠吾, 安齋紗保理, 猪股寛裕, 齋 藤 光, 津田瞳美, 中島友晴: 高齢者に対するサーキット 式コンバインドトレーニングの日常活動量への効果, 体 力科学, 64: 305-314, 2015. doi: 10.7600/jspfsm.64.305.

16）新井智之, 藤田博曉, 細井俊希, 森田泰裕, 石橋英明 : 地 域在住高齢者における足趾把持力の年齢, 性別および 運動機能との関連, 理学療法学, 38: 489-496, 2011. doi: 10.15063/rigaku.KJ00007731336.

17）山口光国, 入谷 誠, 大野範夫, 永井聡, 山膳勉, 福井 勉 : 片脚起立時での足趾屈筋群の役割について, 運動生理, 4: 65-69, 1989. doi: 10.1589/rika1986.4.65.

18）村田 伸：開眼片足立ち位での重心動摇と足部機能と の関連, 理学療法科学, 19: 245-249, 2004. doi: 10.1589/ rika.19.245. 